\title{
Cloning and Sequencing cDNA Encoding for Rhoptry-2 Toxoplasma Gondii Tachyzoite Local Isolate
}

\section{Wayan T. Artama ${ }^{1,3^{*}}$, Yulia Sari ${ }^{1,4}$, Didik Tulus Subekti ${ }^{2}$, Soenarwan Hery Poerwanto ${ }^{4}$ and Jarot Subandono ${ }^{5}$.}

1. Research Center for Biotechnology, Gadjah Mada University, Yogyakarta 55281, Indonesia.

2. Research Institute for Veterinary Science, Bogor, Indonesia.

3. Faculty of Veterinary Medicine, Gadjah Mada University, Yogyakarta 55281, Indonesia.

4. Faculty of Biology, Gadjah Mada University, Yogyakarta 55281, Indonesia.

5. Faculty of Medicine, University of Surakarta, Indonesia.

\begin{abstract}
Rhoptry protein belongs to an excretory and secretory antigens (ESAs) that play an important role during active penetration of parasite into the cell target. This protein an able Toxoplasma gondii to actively penetrate targeted cell, meanwhile ESAs protein stimulates intracellular vacuole modification. It is, therefore, after the parasite successfully enter the cell target then Granule (GRA) proteins are responsible for the formation of parasitophorus vacuole, which is protect the fusion with other intracellular compartments such as lysosomal vacuole. Consequently, this parasite is being able to survive and multiply at the cell target. The current study was aimed to clone and sequens cDNA encoding for ROP-2 of local isolated T. gondii tachizoite through DNA recombinant technique. Total ribonucleic acid (RNA) was isolated from tachyzoites of local isolated T. gondii that were grown up in Balb/ $c$ mice. Messenger RNA was isolated from total RNA using PolyAtract mRNA Isolation System. Messenger RNA was used as a template for synthesis cDNA using Riboclone cDNA Synthesis System AMV-RT. EcoRI adaptor from Riboclone EcoRI Adaptor Ligation System was added to Complementary DNA and than ligated to pUC19. Recombinant plasmid was transformed into E. coli (XL1-Blue). The transformed E. coli XL-1 Blue were plated on LB agar containing X-Gal, IPTG and ampicillin. Recombinant clones (white colony) were picked up and grown up in the $\mathrm{LB}$ medium at $37^{\circ} \mathrm{C}$ overnight. Expression of recombinant protein was analysed by immunoblotting in order to identify cDNA recombinant wich is express ESA of T. gondii local isolate. Recombinant plasmid were isolated using alkalilysis method and were elektroforated in 1\% agarose gel. The isolated DNA recombinant plasmid was cut using Eco RI and then sequenced through Big Dye Terminator Mix AB1 377A Sequencer using M13 Forward and M13 Reverse primers. The conclusion of this results showed that the recombinant clone was coding for excretory and secretory protein which has molecular weight of $54 \mathrm{kDa}$. The DNA alignments of sequence from the cloned gene showed $97 \%$ homology with gene encoding for ROP-2 of T. gondii RH isolate.
\end{abstract}

Keywords: Toxoplasma gondii, tachizoite, ESA, complementary DNA, ROP2

\section{Backgrounds}

Toxoplasma gondii is an intracellular parasite, infect all warm blooded animals including human. This parasite is belonging to an opportunistic pathogen and considered as a master of mind of toxoplasmosis (Dutta et al., 2000). Toxoplasmosis is one of an

*Corresponding author: Wayan T. Artama, Department of Biochemistry, Faculty of Veterinary Medicine, Gadjah Mada University, Yogyakarta-55281, Indonesia. Tel: 62-274-560865; E-mail: wayan_artama@ugm.ac.id extensively diseases spread worldwide in mammals. However the disease prevalence is vary based on geographic and climate condition. In general, an infected mammal with good immune system does not develop any symptoms. When the immune system is adversely weakened, the symptoms are likely to be manifested such as encephalitis and ocular lesion (Yamamoto et al., 2000; Martin et al., 2000). The most excellent step to decrease prevention risk hit toxoplasmosis compared to medication (Wisnuwardhani, 
1990). Mohammed et al. (1994) suggest that in order to decrease the risk of toxoplasmosis at foetus is by vaccination before pregnancy.

The vaccine of diluted tachyzoites $T$. gondii (live attenuated) was reported can prevent abortus in an animal and the sheep have been already used commercially (Alexander et al., 1996). The constraint of toxoplasmosis vaccines by using intact parasite among others is treatment of tachyzoites which is not peaceful expensive and also felt concerned about to become virulen strain, especially in human which is having trouble at their immune system. The progress of a toxoplasma vaccines for human being shall pursuant in the direction of usage of recombinant antigens or a synthetic peptide which perfectly given protection for hospes from all life cycle phase $T$. gondii (Prigione et al., 2000).

Toxoplasma gondii is a Protozoan parasite, living obligate in the any type of nucleated cell (Sibley et al., 1995). Tachyzoite has secretory bodies. The main immunogenic proteins of such secretory bodies are surface antigen (SAG), granulocyte antigen (GRA) and rhoptry antigen (ROP) (Pfrepper et al., 2000; Nischick et al., 2000; Guanjin et al., 2001; Reichmann et al., 2000; Martin et al., 2000). Those three proteins act as a facilitator of host cell infection, invasion and parasitophorus development (Ajioka, 2001).

The antigen especially SAG and ESA has a direct relationship with immunopathogenesis and cell invasion. Surface antigens is related with attachment process into membrane of infected cell. While ESA plays an important role in active penetration process and modification of parasitophorus vacuole in the cell targeted. Each of antigens is consisted of several antigen proteins in which respective protein has different functions.

Cesbron-Delauw et al. (1996) found a given ESA antigen with Incomplete Freud Adjuvant (IFA) was able to protect mice from oral infection in lethal dose of $T$. gondii cyst (survival rate was 50-60\%). Fischer et al. (1998) and Jacobs et al. (1999) conducted a $29 \mathrm{kDa}$ dense granule antigen (GRA7) related study, while Vercammen et al. (2000) investigated a $23 \mathrm{kDa}$ dense granule antigen (GRA1), GRA7, 54kDa rhoptry antigen (ROP2) as well. ESA protein has a higher complexity compared to SAG based on protein variation as pathogenesis factor. Penetration of Toxoplasma into targeted cells give a response of releasing a certain ESA protein. In addition, ESA protein causes parasitophorus vacuole to be unable to fuse with other intracellular compartment such as lisosomal vacuole (intracellular vacuole modification). Consequently, $T$. gondii tachyzoites are able to survive and freely multiply in the infected cell.

The effective and efficient vaccines at the moment are required, therefore DNA recombinant technology is expected can solve internal issue of ESAs which are immunogenic enough for that purposes. DNA recombinant can also given a standing by solution of DNA vaccine or probe for toxoplasmosis.

The current study is aimed to clone and to identify cDNA encoding ESA of local isolated T. gondii tachyzoites through DNA recombinant technique.

\section{Materials and Methods}

Excretory- secretory antigens (ESA) isolation from tachyzoit of Toxoplasma gondii

Excretory-secretory antigens were obtained from local isolated T. gondii, by cultured the tachyzoites $\left(10^{9}\right.$ tachyzoites / $\mathrm{ml}$ ) in RPMI 1640 medium supplemented by $10 \%$ FCS. The suspension of tachyzoites was incubated in $37^{\circ} \mathrm{C}$ for $3 \mathrm{~h}$ by continuously agitation. Following the incubation, the suspension of tachyzoites was centrifuge on $3500 \mathrm{rpm}, 4^{\circ} \mathrm{C}$, for 10 
min and the obtained supernatant was ESA protein. ESA protein was identified by SDSPAGE and stained using $0.2 \%$ coomasie brilliant blue R-250.

\section{Production of polyclonal antibody against ESA protein}

The ESA protein was used as an antigen to induce polyclonal antibody production. Five female mice (BALB/c strain), age 8-10 weeks, each was immunized by intraperitoneal routes using $5 \mu \mathrm{g}$ of ESAs protein in the solution containing of phosphate buffered saline and IFA (incomplete freund adjuvant) in equally volume (1:1) Immunization was repeated 5 times with two weeks interval. The obtained serum (polyclonal antibody against ESA protein) was used for screening of recombinant ESA protein.

\section{Total RNA Isolation}

Total RNA isolated from tachyzoites $T$. gondii local isolate using Total RNA isolation kit (Promega) as described by manufacturer. Messenger RNA was isolated from total RNA using PolyAtract mRNA Isolation System (Promega). The procedures consist of annealing probe, washing $S A-P M P S$, capture of annealing oligo (dT)-mRNA hybrids and mRNA elution.

\section{The cDNA synthesis}

Messenger RNA was used as a template for cDNA synthesis using Riboclone cDNA Synthesis System AMV-RT (Promega). EcoRI adaptor from Riboclone ${ }^{\circledR} E c o$ R I adaptor Ligation System was linked to the phosphorylated cDNA and the adaptors excess was removed using Sephacryl S-400.

\section{Ligation of cDNA into expression vector. \\ One microliter pUC19 $(200 \mathrm{ng} / \mu \mathrm{l})$ was added with $2 \mu \mathrm{l} c D N A$ kinase, $1 \mu \mathrm{l} \mathrm{ATP}, 1 \mu \mathrm{l}$ $10 \mathrm{X}$ buffer T4 DNA ligase and nuclease free water until final volume $10 \mu \mathrm{l}$, then}

incubated at $16^{\circ} \mathrm{C}$, for overnight. Dephosphorilated pUC19 was ligated to previously modified cDNA.

\section{Bacterial transformation}

Before transformation, Escherichia coli XL-1 Blue competent were prepared by fresh exponential phase bacterial culture (OD 600 $\left.\mathrm{e}^{\prime \prime} 0,5\right)$ in LB medium containing 10\% PEG $6.000(\mathrm{w} / \mathrm{v}), 5 \%$ DMSO (v/v) and $35 \mathrm{mM}$ $\mathrm{MgCl}_{2}$. Different concentration of transformed bacteria were spread on LB agar plate containing ampicillin, X-Gal and IPTG then incubated at $37^{\circ} \mathrm{C}$ for overnight. White bacteria colonies were picked up and grown in $5 \mathrm{ml} \mathrm{LB}$ medium containing ampicillin for overnight. The growing bacteria were centrifuge at $4,000 \mathrm{rpm}, 10 \mathrm{~min}, 4^{\circ} \mathrm{C}$ and the pellet was extracted for further plasmid preparation.

\section{Analysis of recombinant plasmid}

Recombinant clones were picked up, grown in the LB medium and incubated at $37^{\circ} \mathrm{C}$ for overnight. Plasmid was isolated using alkalilysis methods, digest with EcoRI and electrophoresis at $1 \%$ agarose gel. Recombinant protein was isolated and electrophoresis at $10 \%$ SDS-PAGE and transfer onto nitrocellulose membrane. Nitrocellulose membrane was stained with amidoblack for protein detection and for immunoblotting, nitrocellulose membrane was incubated with polyclonal antibody against ESA protein.

\section{cDNA Sequencing}

The recombinant plasmid was sequenced at Molecular Biology of Eijkman Institute, Jakarta using Big Dye Terminator Mix ABI 377A sequencer. DNA alignment analysis was performed using NCBI Blast and Clustal W. 


\section{Results and Discussion}

\section{The ESA protein profile}

Excretory-secretory antigens is defined as total protein that secreted and excreted from tachyzoites $T$. gondi. Those proteins are composed of the mixture of all dense granule, rhoptry and micronema proteins (Cesbron-Delauw, 2001). The ESA's profile were shown in several protein as known at $13 \mathrm{kDa}, 14 \mathrm{kDa}, 17 \mathrm{kDa}, 37 \mathrm{kDa}, 44 \mathrm{kDa}$, $54 \mathrm{kDa}, 71 \mathrm{kDa}, 81 \mathrm{kDa}, 98 \mathrm{kDa}, 113 \mathrm{kDa}$ and $131 \mathrm{kDa}$ (Cesbron-Delauw, 2001).

In order to define ESA's expressed from recombinant bacteria was analyzed based on molecular weight in the $12 \%$ SDS-PAGE as shown in Figure 1.

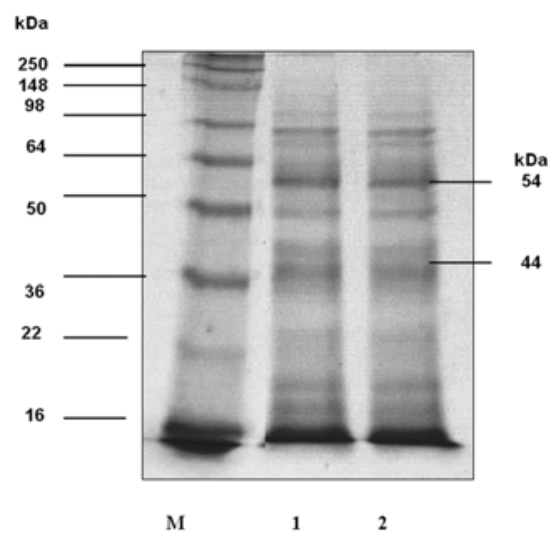

Figure 1. Profile of ESAs protein tachyzoites Toxoplasma gondii M: protein marker; lane 1 and 2. ESA protein

\section{RNA of Toxoplasma gondii}

The total RNA of Toxoplasma gondii was run on 1\% agarose gel was shown in Figure 2. Messenger RNA (mRNA) was isolated from $4.392 \mu \mathrm{g} / \mu \mathrm{l}$ total RNA using PolyATract mRNA Isolation System. In this regard the yield of mRNA was sufficient for twice synthesis of cDNA.

\section{Recombinant plasmid analysis}

Plasmid from recombinant clones were isolated using alkalilysis method and electrophoresis on $1 \%$ agarose gel. The result was shown in Figure 3.

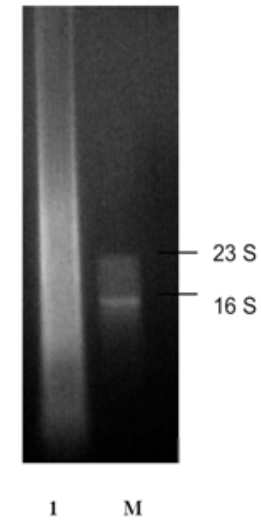

Figure 2. Electrophoresis of Total RNA Toxoplasma gondii local isolate M. Marker RNA ribosom, lane 1. Total RNA

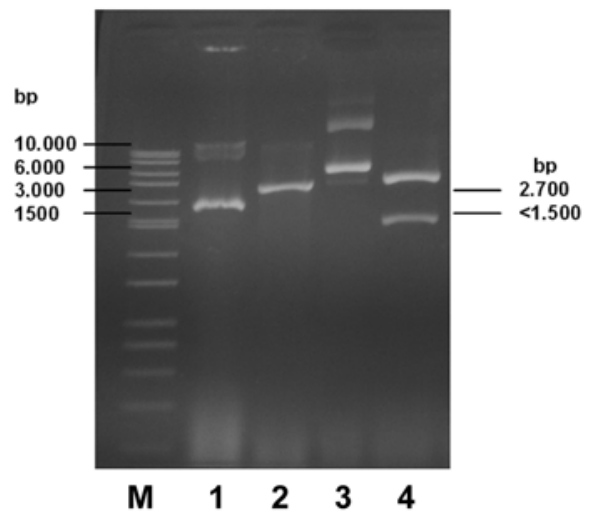

Figure 3. Electrophoresis of plasmid on $1 \%$ agarose gel M. Marker, lane 1. undigested pUC19, lane 2. pUC19 digested with Eco R1, lane 3. Recombinant Plasmid, lane 4. Recombinant Plasmid digested with Eco R1

\section{Recombinant protein identification}

The profile of recombinant protein in line 1 was compared with the control $(E$. coli XL-1 blue) and blue colony showed different profile of ribbons.

The profile of recombinant protein in the $1^{\text {st }}$ line, if it is compared with the marker, showed presumably a $54 \mathrm{kDa}$ protein expression. The molecular weight of ribbon of recombinant protein in line 3 was $54 \mathrm{kDa}$, calculated by regression equation 
(attachment 8). Recombinant of Excretory Secretory Antigens (ESA) with molecular weight $54 \mathrm{kDa}$ was identified as ROP 2 protein.

Recombinant colony lisate protein in line 1 showed different pattern of ribbons with those from blue colony and E.coli Xl-1 Blue. The obtained protein was identified by electrophoresis in $12 \%$ polyacrilamide gel. The result is showed in Figure 5.

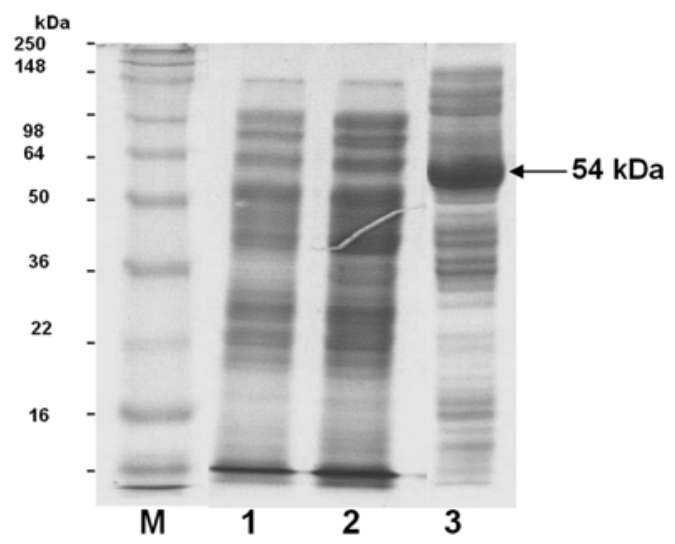

Figure 5. Profile lisat recombinant protein in $12 \%$ polyacrilamid gel M. Protein Marker, Lane 1. Recombinant Protein, Lane 2. E.coli XL-1 Blue Protein And Lane 3. Blue Colony.

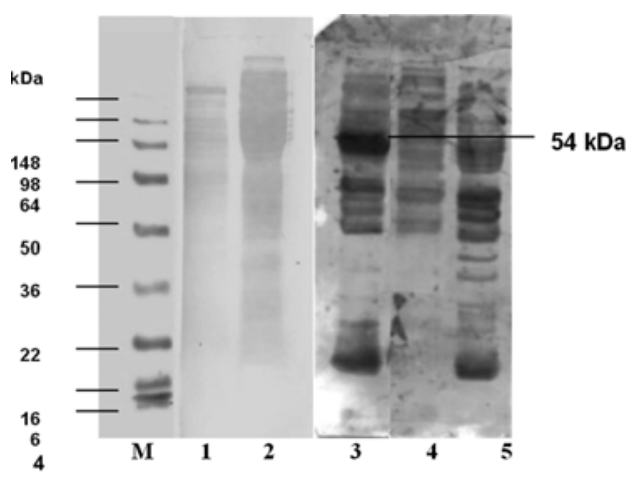

Figure 6. The Immnublotting of recombinant Protein from SDS-PAGE 12\% with antibody polyclonal to ESA. M. Marker, Lane 1. Lisate protein E. coli XL1-Blue, 2. lisate recombinant protein, Lane 3. lisate recombinant protein, Lane 4 . Lisate protein E. coli XL1-Blue (without pUC19), Lane 5. lisate protein blue colony (pUC19 whithout insert)
The result of immunoblotting of several recombinant protein with antibody polyclonal towards ESA protein is showed in Figure 6. The importance result of the recombinant protein is able to applied for vaccine candidate or strong inducer of immune response (Vercammen et al., 2000).

\section{DNA sequencing}

Sequencing was done by the use of pUC/M13 forward sequencing primer and pUC/M13 reverse sequencing primer in the available pUC19 vector construct (Promega). Sequencing with pUC/M13 forward had resulted a $719 \mathrm{bp}$.

The sequence was analyzed with BLAST program to identify the cloned gene. Sequence that showed a significant alignment was ROP2 protein-encoding gene of T. gondii RH isolate. Recombinant DNA sequence alignment was showed 97\% homology with ROP2 gene of the $49^{\text {th }}$ base to the $561^{\text {st }}$ base $\mathrm{RH}$ isolate (Figure 7).

Sequencing of plasmid recombinant was done with pUC/M13 forward sequencing primer and $\mathrm{pUC} / \mathrm{M} 13$ reverse sequencing primer (available at pUC 19 vector construct/Promega). The analysis of the DNA sequence obtained from the BLAST program revealed a significant degree with gene encoding rop $2 T$. gondii $\mathrm{RH}$ isolate. Sequence alignment sequenced using pUC/M13 forward showed 99\% homolog from base 49 until 561. Alignment sequence which sequenced using $p U C / M 13$ reverse showed $95 \%$ the differences were lied on base 967 and 1628. The difference bases at 1330 did not change the amino acid; (GTT to GTC: Valine ), difference at 1500 did not change the amino acid; (TGC to TGT: Cysteine), and difference at 1592 lead to alter amino acid glutamic acid (GAA) to alanic acid (GCA). Transformation of glutamic acid into alanic acid, in the chemical structure, is not significantly different. It is, therefore, no change on 


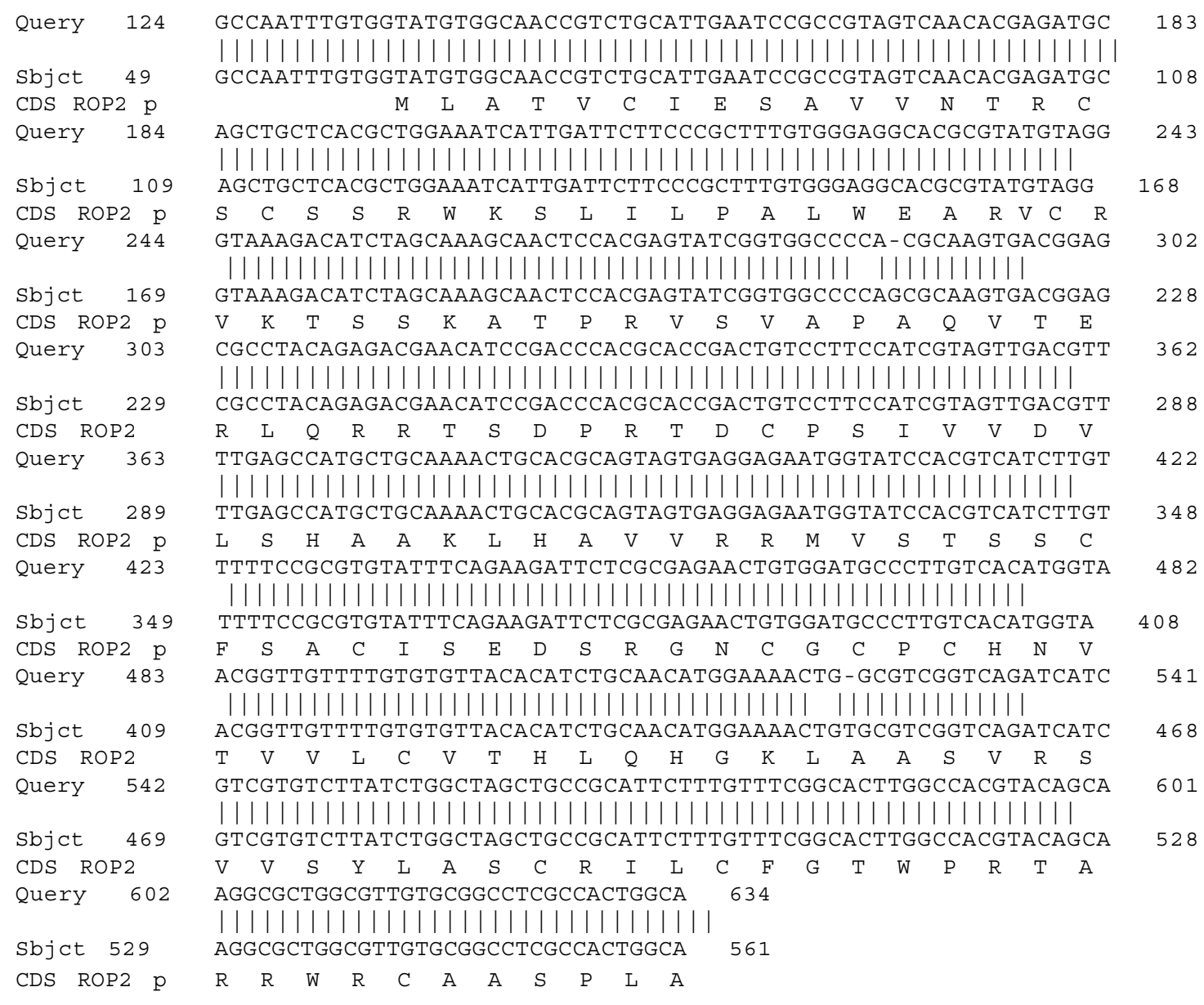

Figure 7. Alignment DNA recombinant (The result of sequence with M13 forward primer) and gene encoding ROP2 $\mathrm{RH}$ isolate.

protein structure as well as no influence on epitope of ESA protein.

\section{Conclusion}

Complementary DNA from T. gondii local isolate was successfully cloned into pUC19 vector and transformed to XL-1 Blue E.coli. The correspondence sequence of cDNA was encoding of a 54-kDa protein. Alignment analysis of the sequenced cDNA was shown $97 \%$ homology with the rop 2 gene of $T$. gondii RH strain.

\section{Acknowledgements}

This work was supported by the Indonesian Research and Technology under the skim of RUT XI. We are very much indebted to Prof. Dr. Sukarti Moeljopawiro for her comment and correction of this manuscript and also Mrs. Arsiyah and Mr. Tukijo for their valuable contributions on this work and maintaining the Toxoplasma isolate. 


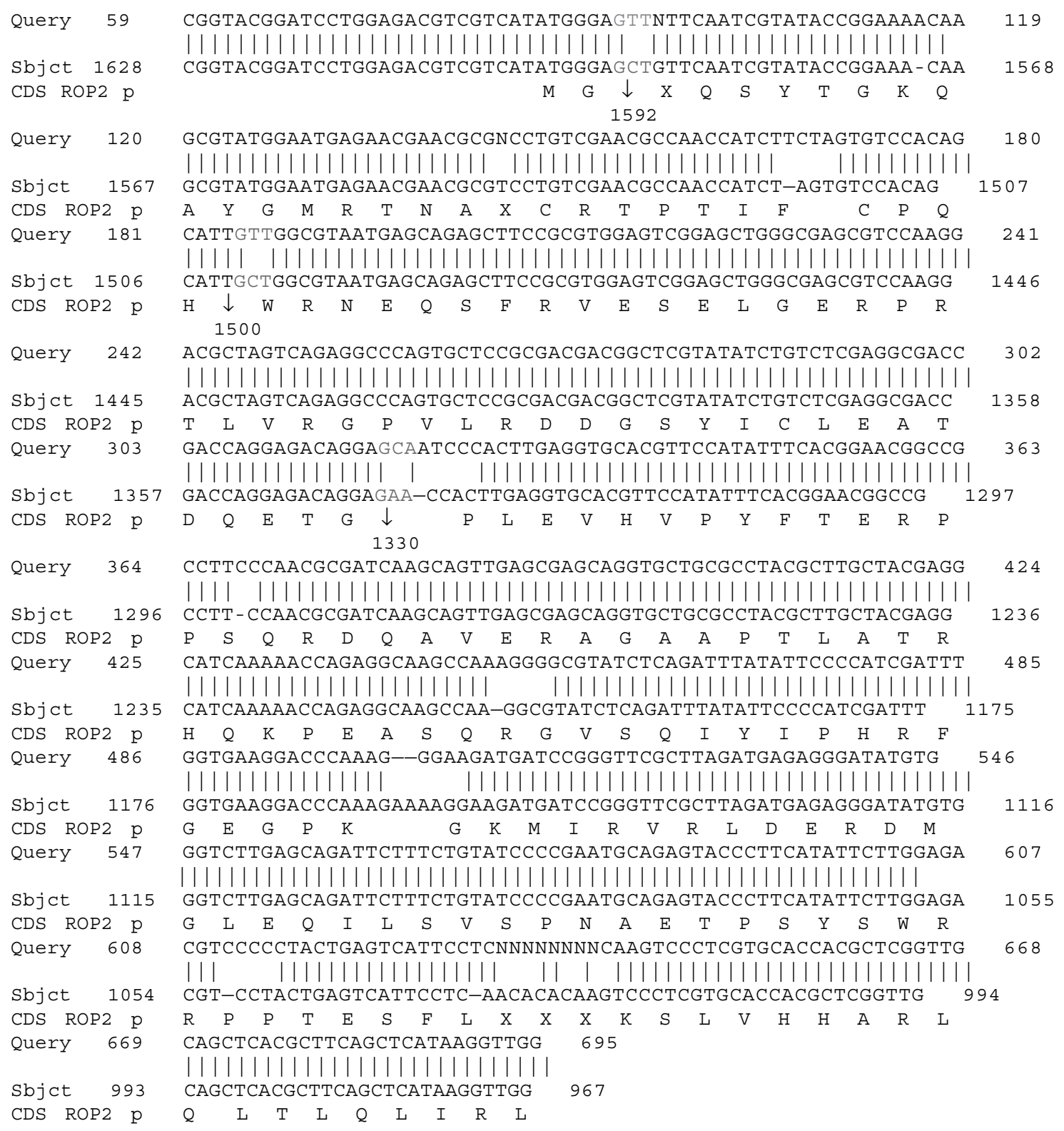

Figure 8. Alignment DNA recombinant (The result of sekuensing with $p U C / M 13$ reverse primer) and gene encoding ROP2 RH isolate.

\section{References}

Ajioka, J.W., Fitzpatrick J.M., and Reitter, C.P., 2001. Toxoplasma gondii genomics: Shedding light on pathogenesis and chemotherapy. http://www-ermm.cbcu.cam.ac.uk

Alexander, J., Jebbari, H., Bluethmann, H., Satoskar, A., and Roberts, C.W., 1996.
Immunological control of Toxoplasma gondii and appropriate vaccine design. In U. Gross, ed., Current topics in microbiology and immunology. Berlin, Heidelber: Springer-Verlag. pp.183195.

Ashburn, D., 1992. History and general epidemiology. In Ho-Yen, D.O. and 
Joss, A.W.L., eds. Human Toxoplasmosis. New York: Oxford University Press. 1-22.

Cesbron-Delauw, M.F., 1996. Role of secretory dense granule organelles in the pathogenesis of toxoplasmosis, In U. Gross, ed., Toxoplasma gondii. Berlin, Heidelberg: Springer-Verlag, pp.59-64.

Dubey, J.P., Lindsay, D.S., and Speer , C.A., 1998. Structures of Toxoplasma gondii tachyzoites, bradyzoites, and sporozoites and biology and development of tissue cysts. Clin. Microbiol. Rev., 267-299

Dutta, C., Grimwood, J., and Kasper, L.H., 2000. Attachment of Toxoplasma gondii to a specific membrane fraction of $\mathrm{CHO}$ cell. Infect. Immun., 7198 7201.

Fuentes, I., Rubio, J.M., Ramirez, C., and Alvar, J., 2001. Genotypic characterization of Toxoplasma gondii strains associated with human toxoplasmosis in Spain direct analysis from clinical samples. J. Clin. Microbiol., 1566-1570

Gazzinelli, R.T., Amichay, D., ShartonKersten, T., Grunwald, E., Farber, J.M., and Sher. A., 1996. Role of macrophage-derived cytokines in the induction and regulation of cellmediated immunity to Toxoplasma gondii. In U. Gross, ed., Current topics in microbiology and immunology. Berlin, Heidelberg: Springer-Verlag. pp.127-136.
Guanjin, C., Hong, G., Fangli, L.U., and Huaqin, Z., 2001. Contruction of a recombinant plasmid harbouring the rhoptry protein gene of Toxoplasma gondii and preliminary observations on DNA immunity. J. Chin. Med., 114 (8), 837 - 840.

Pfrepper, K.I., Enders, G., Gohl, M., Krczal, D., Hlobil, H., Wassenberg,D., and Soutschek, E., 2005. Seroreactivity to and avidity for recombinant antigens in toxoplasmosis. Clin. Diagn. Lab. Immunol., 12 (8), 977-982.

Sibley, L.D. and Howe, D.K. 1996. Genetic basis of pathogenecity in toxoplasmosis. In: Current Topics in Microbiology and Immunology., Gross, U. (ed.). Berlin, Heidelberg: SpringerVerlag. pp.3-13.

Vercammen, M., Scorza, T., Huygen, K., De Braekeleer, J., Diet, R., Jacobs, D., Saman, E., and Verschueren, H., 2000. DNA vaccination with genes encoding T. gondii antigens GRA1, GRA7 and ROP2 induces partially protective immunity against lethal challenge in mice, Infec. Immun, 68, 3845.

Yamamoto, J.H., Vallochi, A.L., Silveria, C., Filho, J.K. Nusenblatt, R.B., Neto, E.C., Gazzinelli, R.T., Belfort, R., and Rizzo, L.V., 2000. Discrimination between patients with acquired toxoplasmosis and congenital toxoplasmosis on the basis of the immune response to parasite antigens. J. Infect. Dis. 181, 2018 - 2022. 